\title{
Time and the Problems of Television: Three Images
}

\author{
Timothy Barker
}

School of Culture and Creative Arts, University of Glasgow, University Avenue, Glasgow G12 8QQ, UK; timothy.barker@glasgow.ac.uk

Received: 24 June 2019; Accepted: 21 August 2019; Published: 23 August 2019

\begin{abstract}
In this paper I look at three images and use them to discuss television and the conditions for the representation of time in the twenty-first century. The first image is from the UK's Channel 4 news report following the November 2015 terror attacks in Paris. The paper begins by offering a theoretical critique of this televisual image and explores the grounding offered for the representation of fear and the contingent. From here, I explore two images from the experimental beginnings of television, which can be seen to provide the historical and technical conditions for the first image. The paper is media philosophical in method, critically analysing the way television can represent time and events by looking to its technical operation and its history as a technology rooted in solutions to time-based problems.
\end{abstract}

Keywords: media philosophy; television and philosophy; time and television; media archaeology

What does it mean to speak about the contemporary? What do we mean when we talk about the contemporaneity of the present? Both of these questions relate to time. Both questions relate to the way the present, as Terry Smith describes it, enacts a type of 'stitching together' of multiple times [1]. Both insist on an answer that addresses the time of the present; a present that is thick with different layers of temporality, different modes of representing time and different experiences of history. In this paper I try to explore these questions by looking at images on television screens. Specifically, I look at three images that allow me to begin an exploration around the way that the temporality of events have been controlled and occasionally expressed by the apparatus of television, as the television attempts to make the multiple into the one.

The first image is one that stopped me in my tracks. Following the 2015 terror attacks in Paris, the UK's Channel 4 aired a fairly conventional news report based on the activities of mourners on the 'home soil' of Europe. The arresting image however, the thing that punctuated the coverage, was something that was both expected and unexpected, similar to the punctum of a photograph. There was a moment that broke through the usual techniques of reporting, an image of fear, an image of the contingent, an image of the event, which erupted through the aftermath of the original attacks and its organisation on screens. From here, the second and third images that I explore-images from the experimental beginnings of television - are ones that can be seen to provide the conditions for the first and that offer to us a media historical way to start to understand the conditions for the existence of these types of contemporary images. As such, the paper moves from a phenomenological analysis of the first image, exploring the way it folds together multiple temporalities, to a media archaeological analysis of the second and third images, exploring how basic technical routines have provided the conditions for the possibility of this experience of time. From a description of these images, two theoretical critiques of the television emerge. The first is one in which a media theory of time, contemporaneity and the image is presented based on technical routines of signal processing and the industrial techniques of producing content. The second critical position to emerge is one that pays attention to the potential lines of escape from this type of controlled time of waiting and repetition, a time that has been referred to by Vilém Flusser as 'post-historical', where the television may express 
new possibilities for experience as it begins to produce its own temporality and as events that it itself sometimes produces erupt through its technical surface [2].

In this sense, the paper begins from a contemporary image-an image of terror and its aftermath - and asks, what is at stake in this image? What is it that makes this image contemporary? What do we mean when we talk about its contemporaneity? What conditions for being-in-time does it present? To answer these questions, we must first offer a way to understand the complexities expressed in the term contemporaneity. This is a term now commonly used to describe the historical present and is designed to capture an intense depth of temporal difference. As a replacement for the conceptualisation of history found in discussions of Western modernity and post-modernity, the term contemporaneity has been used in cultural theory, art theory and philosophy to discuss new ideas about the multiple, and often conflicting times, memories and histories of the present in global, twenty-first century culture. Modernity was described as marked by a type of time that was one-dimensional, progressive and oriented towards the production of a shared future. Post-modernity, on the other hand was conceived as, among other things, the aftermath of this type of time. The term contemporaneity is a way of getting beyond a one-dimensional model of time, framed solely via the concept of progress and history, as moments with clear boundaries, bracketed of from one another. It instead encourages thinking about the present as a conjuncture of other, multiple and sometimes conflicting versions of time.

Giorgio Agamben [3], Terry Smith [4], Peter Osborne [5], and Juliane Rebentisch [6], amongst others, have offered ways to understand the term contemporaneity by either looking to aesthetics or looking to the infrastructures that support and give shape to the artworld. The way individual artworks deal with time and conflicting histories has been closely studied, as has been the character of global art markets and the Biennale condition. What has received less attention however is the technical infrastructure of everyday image making and image consumption and the notion of the representability of time against this background. How, for instance, does the apparatus of contemporary television afford itself particular ways of representing time? How does the apparatus' operation in time support the ways that it allows viewers to understand and engage with time-based phenomena, including memories and histories? These are the question that I start to explore in this paper and ones that are necessary to come to terms with the conditions for speaking about and representing time in twenty-first century media culture.

Questions of time and temporality have been a major part of the discipline of television studies. Raymond Williams most famously tuned scholars into this when he told us to focus on the programming of time-discrete units (programs and ads) into a televisual 'flow' [7] (p. 89). Major scholars such as Paddy Scannell [8], John Fiske [9], Stephen Heath [10], and Mimi White [11], focusing on the programming, production and delivery of television content, have also added field defining concepts to the discussion. Topics such as flow, liveness, the glance and more recently time-shifting and mobile viewing seem to characterise the television as a medium that gives viewers unique access to technically produced forms of temporality. For some media theorists and philosophers, such as Stiegler [12], Flusser [2], and Virilio [13], the television and other new technologies of vision not only generate temporality but bring with them what might be seen as a cultural loss of history and memory [14,15]. As the television image disappears into the communication chain, as it becomes a volatile electric charge, it is not able to be archived in the way print, photography or film once was. Pre-digital television did not record events in order for them to be archived. The events disappeared, as Kittler described it, into the black hole of wires and circuits as soon as they were registered by the camera [16] (p. 316). Television did not produce a storage time, like print or film. Instead it produced the temporality of events as they happened. It focused attention on the contemporary, on a type of presentism, on being in the time of the present. And because of this it is a good medium to use to begin to produce contemporary theory (or theory that is about the difficulties of being in the time of the present and the type of terror that it can make present). 
The task of contemporary theory is to bring into view the time of the present in order to open lines of critiquing this present. For contemporary theory to be useful, the difficulties of being-in-the-present need to be brought into view, which includes the conditions of living in crisis, the conditions of time without a single history, and the condition of multiple temporalities. These descriptions however are not simple naïve observations, aimed only at capturing a slice of the present moment. Instead they are designed to be clinical in that they seek to investigate the present moment and the role media, specifically the television, plays in our sense of time. This is undertaken not simply to describe what is 'going on' in the twenty-first century, but to begin to describe the conditions for the possibility of representation and to chart their effects. In this sense the essay practices a media technical inflected discourse analysis [17], focusing on the way that techniques and technologies in the history of television have provided the ground for the representability of time.

The three images are used to describe three different, but related versions of television time: The first image is used to discuss the idea of waiting time (waiting for something to happen), the second is used to discuss the idea of pixels or the particalisation of the image (and what this means for the conditions of representation, and the representability of time) and the third is the technique produced by television of 'seeing up close', and how this is a temporal, as well as spatial phenomena, due to its undergirding by technical solutions to the problem of time.

As alluded to above, this paper is media archaeological in method, focusing on the technical operation of television as a particular time-critical set of processes [18]. Media archaeology is often associated with a particular German-style of media theory (although its practitioners are not always German). It is an approach that focuses on the technological aspects of media and often (though not always) tries to uncover the cultural effects of the operation of technology. This becomes particularly appropriate when thinking about questions of the representation of time and the way that this may characterise a condition of contemporaneity because it suggests an approach that looks to the conditions for representation, rather than the representation itself. And by this, the media archaeological approach may enable us to get beyond the ideologies of liveness and flow as a type of 'essence' of the medium of television, as Jane Feuer first identified, and instead direct theoretical critique toward an exploration of the technical conditions for 'segmentation without closure' [19] (p. 16), for the apparent never-ending fragmentation of television images. Different to Feuer's original approach however, the media archaeological method pushes critique beyond the interpretation of on-screen content and the methods of network production. Instead, media archaeology allows us to uncover the technical conditions for fragmentation that need to operate for there to be any content in the first place.

On Saturday 15 November 2015, two days after the tragedies in Paris, the UK's Channel 4 news man Matt Frei stood in front of a camera in the Place de la République (Figure 1). The Channel 4 coverage of the aftermath of this event had been carefully organised into a 'flow', as Raymond Williams first described it. ${ }^{1}$ This however was not a flow that pointed towards the future but rather a flow of information designed to extend the aftermath of the original event, to repeat its significance by repeatedly folding the past into present realities. The linear flow of television was replaced by the virtual-actual circuit. Carefully timed transitions took place from locations around Paris, where reporters described the new contexts produced by terror. One Paris location was followed by the next, one commentary followed by another. Controlled sections of time were strung together on-screen to construct a news report. However, this circular flow became disrupted in Frei's report. Only a short time into Channel 4's coverage, the crowd panicked and ran wildly in all directions, with Frei and the camera struggling to grasp the event, jostling with the crowd. Time crystallized in this moment [20] (p. 76). The flow became replaced by a more complex mixture of movement. Breaking through the rational and analytical organization of scenes, was what Paul Virilio calls the violence of the accident,

1 The production of these types of media events have been described by media anthropologists (Sumiala 2013; Lule 2001; Dayan and Katz 1992; Couldry 2003) interested in the contemporary rituals of mediation. 
the mystery of speed: 'with speed, the world keeps on coming at us [ ... ]. It is the intervention that destroys the world as we know it' [21] (p. 110). The speed of crisis, the flow in all directions replaced the world of one-thing-after-the-other. In the aftermath of the terrorist events of Friday evening, aimed at television screens, Frei was apparently reporting on the memorial activities of the crowd of Parisian mourners. But something else erupted-an event the seemed to exceed the medium's capacities. This amounted to the arrival of a figure-a figure of terror - that the television cameras invited but did not expect; this was a figure that was both there and not there, virtual and actual, present and not at the same time.

\section{Image 1: Waiting}

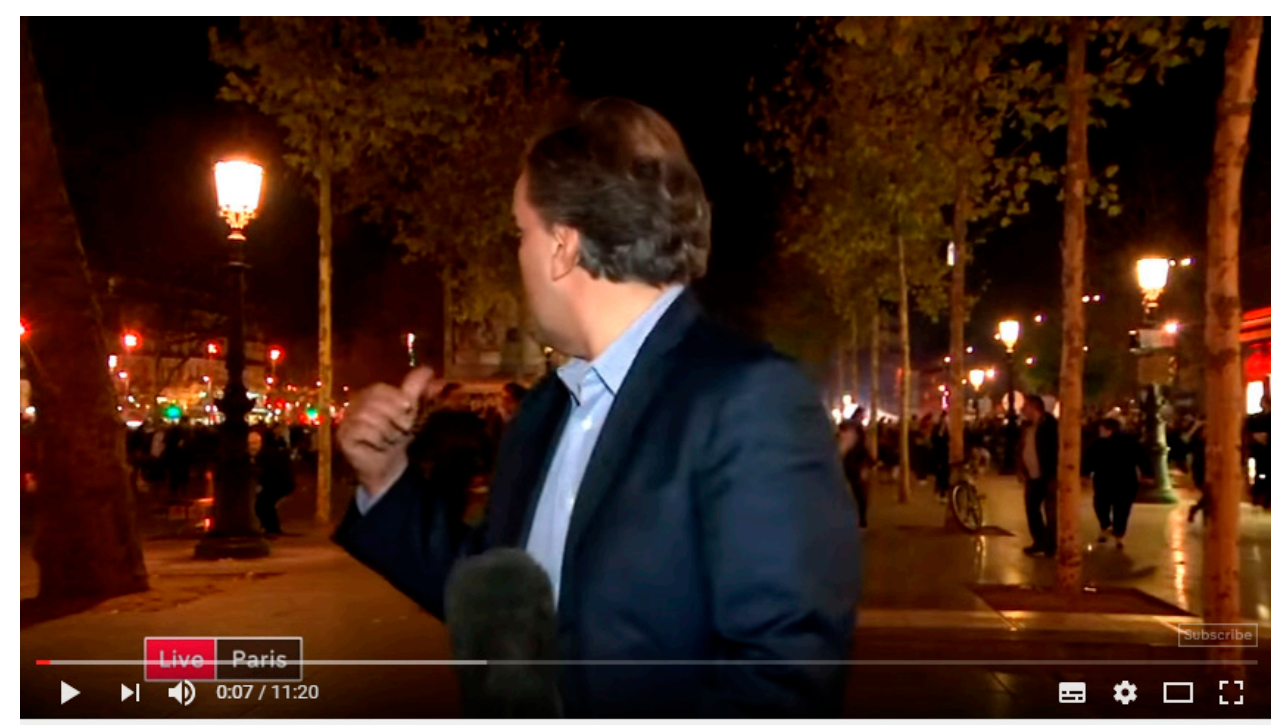

Matt Frei's live report as crowds run in panic

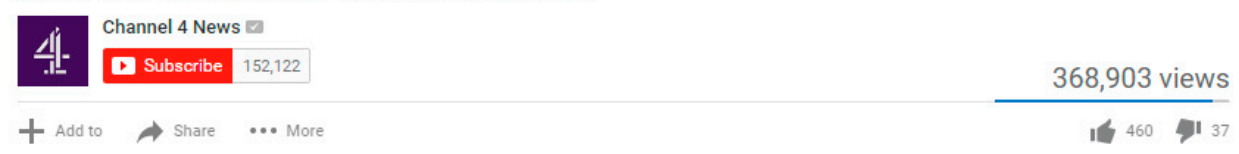

Figure 1. Frei reporting on the aftermath of the 15 November 2015 terror attacks in Paris.

The types of scenes that Channel 4 reported in the aftermath of terror have become ubiquitous. But what was unique about Frei's coverage was the moment of fear that it captured and the temporality of chaos and the contingent that it represented, as though a crescendo had been reached. There both was and was no enemy in the image. We are waiting for what terrifies us, for something or someone to arrive. Television coverage sets up this waiting time. There was no terrorist in the broadcast but what was palpable and agentive was the threat of an enemy in the image of mourners on the 'home soil' of Europe [22] (pp. 157-159); the threat erupted through the waiting time. The speculative, the invisible, but very real element provided the conditions for the possibility of experience.

The history of Paris, the violence, the military occupations of the past, provided one sense of being-in-time, the time of history. The anticipation of the future, the apprehension of what is to come, the waiting, provided another. The history of terrorism, global scars that the west lives with, the aftermath, tangible, present signs of trauma, provide yet another. All of these times are folded into the present. All of these times are re-read through the prism of the unfamiliar, the monstrous present. This condition produced the catastrophe; a violent, sudden turn, which lasted only seconds, giving body to a vibrating tension of nervousness, which was captured by the broadcast news crew.

Frei exclaims, 'I think I heard a gunshot ... but I'm not sure if that's true'. When the crowd turned and started running, Frei, swept up in the event, the professional reporter taking on the role usually reserved for the citizen journalist, scrambled for a sense of the scenic significance of the moment. 
The television apparatus was still trying to make a scene out of the scrambling crowd, fleeing what they heard as a gunshot. We were no longer waiting. The event of terrorism, the event that was ongoing days after the shooting, turned into a scene by the ritual of the television report, became again, before our eyes an event. Fear, chaos, uncertainty and the unexpected was again mobilised in the image.

Everything unexpected is terrifying. But only these unexpected events are able to transform our current forms of waiting [2] (p. 122). We wait for what terrifies us. 'What is going to happen? What just happened? The agonising aspect of the pure event is that it is always at the same time something which has just happened and something about to happen' [23] (p. 42). As Paul Patton writes, instances of becoming such as these events break through into history. The catastrophic, the violent, break the surface of the analytic organisation of scenes. The organisation of scenes into tractable picture elements, as will be discussed in what follows, is actually what the TV is predicated on, technically speaking, as it segments light into bands. The catastrophic event however breaks the surface produced by these merely ontic operations 'They exhibit the hermeneutical sublime in the highest degree insofar as they realise the potential to break with existing frameworks of understanding' [23] (p. 43).

But it was not long before television dealt with the eruption of the event. Electronic media, the rituals of reporting, the negotiations between the technical image and the storytelling practices of journalists take history as an input and give us what Flusser calls post-history as an output [2]. Media—the television—define the situation —-they order the event according to their own operating principles. The violent turning of catastrophe was in no time at all again turned back into the flow of scene after scene. If cinema, when it works, produces the crystal-image that Deleuze describes, then television only produces the crystal-image when it stops working, in its moments of crisis. To prevent this, to produce television as a flow, it is back to the news anchor. Events are turned back into programs. The ecstatic time of the emergency returns to the segmentation of one discrete thing after another [24] (p. 242). But we still wait for more terrifying news. We look for what terrorizes us. We continue to wait. We balance the terror under which we live with the television. It is not the liveness that offers the feeling of cohesion and togetherness [25] but the aftermath of the event, replayed, now stored on YouTube in a relational structure.

Shortly after the initial panic, the coverage returned to John Snow, the main news anchor, reporting from Notre Dame, to quite obviously give an authoritative voice to the contingent goings on, to again enact the media rituals associated with reporting terror. It was here that the coverage returned to what Kirsten Mogensen described as the norms of reporting at a time of crisis. The television, as a type of 'first aid' in the face of terror, attempts to 'at the same time stimulate[] rational thinking and limit[] the negative stimulus of the feelings and senses' [26] (p. 36). It acted both as a witness and also, particularly as it was reporting on 'home soil', a way of comforting the witnesses of the shared traumatic event. This is why, in the Channel 4 coverage, television, in the face of chaos, returned to its ordering of the event in almost no time at all. After an initial shock, where liveness was in excess, the present was re-ordered, filtered, by the 'formatting' of television and returned to its status as a scene. We continue to wait for more information, more images. The waiting time, the togetherness, the contemporaneity, the being-in-waiting-time, is set up by the programming of the apparatus of television, both in terms of the practice of programming media events and the technical operation of the transmission medium.

"When we get close to a screen we see points-pixels" [27] (p. 34). Television images are not in fact images at all, but rather the results of chemical or electronic processes. The output of technical processes, the image amounts to an arrangement of pixels, particles or micro-elements of time and it is through this process that images become, according to the media philosophical reflections of Flusser, 'post-historical'. The event becomes represented based on this process of particalisation and transmission. The world that is shown to us is organised based on the technical principles of the television. Viewers are presented with particles of information organised by programs. These technical conditions provide the conditions, the grounding, for discourse. In the television we see what Marshall McLuhan would call both the figure, the topic of reporting, but also the ground, the condition for this figure. We see the figure: the image of the crowd, Frei knocked out of the way. We see the ground of 
fear and threat and the anxiety of that which will not last and of that which is to come. What happened? What is about to happen?

To begin to think through these question we can look back, through the rearview, to a much older image, before the problems of television were solved. Doing this, we might see how media devices have been developed to control the event and to begin to attempt to conquer time. To answer the question of what it feels like to view contemporary television images and how they might produce versions of contemporaneity, in the next section I'd like to shift perspectives to look at the media technical preconditions for the production of television images in the first place and explore how events such as Frei's report both work against and are then territorialized by these technical conditions.

The Bildtelegraph (Figure 2), developed in the early 1900s by Arthur Korn, is certainly not the only nor the first example of what we might call pre-television technology, but this is probably the one where the idea of breaking down an image into what is transmittable is most obvious.

\section{Image 2: Transmission and segmentation.}

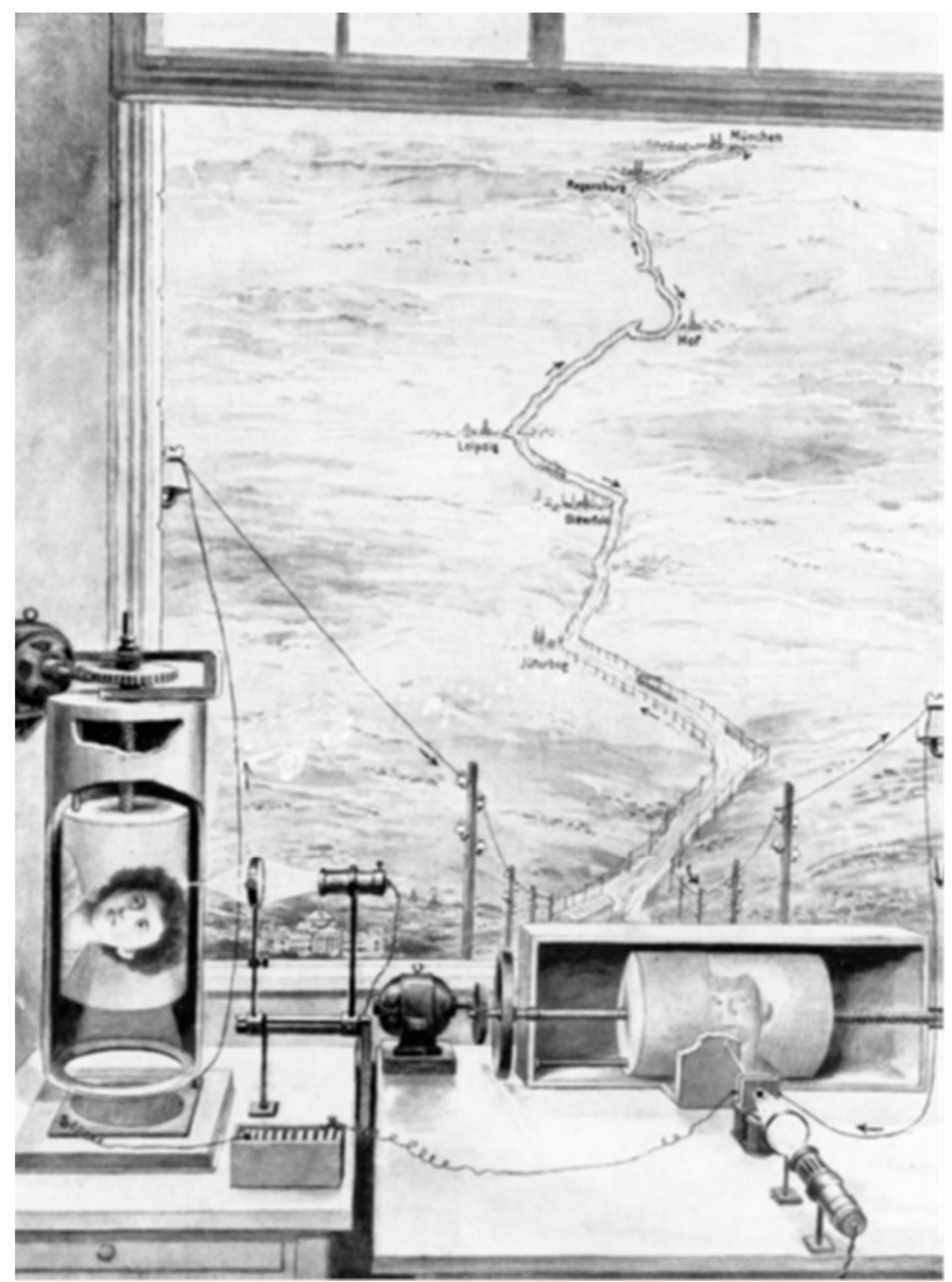

Figure 2. Illustration of the Bildtelegraph. (C) Stiftung Deutsches Technikmuseum Berlin, Historisches Archiv. 
The Bildtelgraph made it possible to transmit an image over distances-making possible a type of seeing at a distance (the literal meaning of television). It was however not able to record movement and was therefore limited to sending still images. The Bildtelegraph worked by the operator stretching a photograph on transparent paper over a cylinder, which was then scanned by a light source. A mirror inside the cylinder would then reflect the light onto a selenium cell, which reacted to the light by alternating its conductivity of electricity. This made it possible for the changes in light as the beam was interrupted by picture elements to be converted into differences in electric charge and then transmitted over telegraph lines.

At this point in media history it was realised that the telegraph could be used not to just send dots and dashes but to transmit signal that could be recomposed to make pictures. The Bildtelegraph and other similar inventions relied on precise synchronisation as the image was drawn one line at a time. Although these devices could not reproduce movement in time, they made operational their own media time in order to synchronise the sender and receiver. This was a media time that was based on unfolding time, on segmenting it into tractable bits, set out on a line, rather than dealing with the eruption of the event or the representation of folded time as seen in the description of the report in Paris. As the image was being drawn line by line, as the image was broken down into its elements and then reassembled, they introduced a waiting time, much like the waiting time offered and then broken by Frei's report. It was also important that the sender and receiver apparatus was in synch-that they were operating on the same time scale.

The segmentation and electrical transmission of images began to be a relatively common place in the mid-1800s. An apparatus designed by the Italian physicist Abbé Caselli called the 'pantelegraph' began to be used for practical purposes in the 1860s. Much like the Bildtelegraph invented later in Germany, Caselli's device enabled the transmission of signatures, handwriting and drawings over telegraph wires. Caselli's invention was itself apparently modelled on an earlier patent by the Scotsman and inventor of the first electronic clock, Alexander Bain. In Bain's device, raised pins (pixels) were scanned by a stylus that transmitted on-off pulses of signal. This signal, operating on the digital principle of switching, would then be transmitted to a receiver that reprinted the pattern on paper that was treated with a mixture of ammonium nitrate and potassium ferrocyanide, making it sensitive to electric current. In Caselli's device letters were painted with a special ink upon tin foil, which was scanned by a pendulum with a stylus attached to its tip. The foil itself was a very conductive material, while the ink applied on top of the foil prevented the conductivity of electric current. After each pass of the pendulum, a mechanism incrementally moved the image perpendicular to the line that was just traced. The result was that the stylus could measure the variation in electric current over each scanned line. This was then transmitted as electricity to a similar apparatus at the receiving end where a stylus would discharge the current on a piece of paper that, like Bain's earlier invention, was treated with a chemical solution sensitive to electric charge.

These were among the first systems to replace the voice of the telephone and the coded messages of the telegraph with images. The telephone and the telegraph presented the receiver with synthetic information - either listening or reading the receiver would assemble the particles of the message into a whole. The image however, although drawn line by line over time, presents a new temporal system, one where a whole is given first and the receiver is left to inspect its elements as their gaze moves over its surface. This signalled a dramatic change to the way information was conveyed. It signified what Flusser would identify as a shift to the era of the technical image, which he would identify as having massive consequences for the way time and history could be represented.

As Flusser argues, to produce the style of communication via technical images, where particles of information are organised by the apparatus rather than the human receiver, the rhythms of the device's operation became important. Both Bain's and Caselli's inventions did not pick up light, but instead via a regulating clock synchronised a scanning stylus at the transmitting end with a writing stylus at the receiving end. However, selenium like that used in the Bildtelegraph was able to pick up light—and it was not long before other inventions used selenium to begin to experiment with the instantaneous 
transmission of images. For instance, Ernst Ruhmer in 1909 discovered that he could send the image of simple geometric shapes over telegraph lines by using an array of selenium cells. The image of a cross could be segmented into nine squares of light and then transmitted across his studio. Selenium is a substance that usually has a very high resistance to the passing of a current of electricity. When exposed to light however its resistance drops by 15 to 30 percent, depending on the intensity of the light. This was to offer the possibility of capturing movement, rather than simply reproducing still images.

Although inventors such as Ruhmer were beginning as early as 1909 to solve the problems of the instantaneous transmission of images, there was another problem of television that proved more persistent: Selenium is sluggish. When light initially hits selenium it gives of a charge, but the substance takes time to recover its properties as a transducer. The early experiments with selenium all pointed to one common feature: instantaneous changes of light on the selenium did not cause instantaneous changes in charge given off by the material [28] (p. 954). The moving image, the event, always withdrew from the selenium, never able to be captured in its perceived completeness. What needed to be done so that events like Frei's news report could be captured was to work out a way for the device to capture and organise time. This is not just technical but may be considered as a cultural technique for organising time. As Mary Anne Doane writes,

The major category of television is time [ ... ]. The television, at these experimental stages amounted to an array of devices that not only represented time, like cinema, but relied at its technical base on time-based concepts such as synchronisation and delay. Sending and receiving devices had to stay in synch with for transmission to take place. It became all the more representative of a time criticality as images would disappear once they were transmitted. The temporal dimension of television [ ... ] would be an insistent present-ness' [29] (p. 251)

The television image was ephemeral, in time, in a way that the photo-chemically fixed cinematic image was not. The television image was captured, held for a brief moment due to the slightest of delays in the wires of the medium. Like cinema, television gave form to time-images. But these were distinct from cinematic time-images based not on their representational character but on their operation in time.

In these experimental stages, television began to work by segmenting the world in front of the transmitter into points of light that could be strung together to make bands. It is in this sense that Kittler refers to the medium as the first to give all-electronic form to Claude Shannon's Mathematical Theory of Information [16] (p. 202). To achieve this, as Kittler pointed out, images would become 'discrete quantities of data' [16] (p. 208).

Delay was a major problem. Selenium lagged. Brighter lights helped but did not solve the problem. A photo-electric cell could stand in for selenium, but this had problems with sensitivity. John Logie Baird would eventually solve these problems by eventually replacing the selenium in his experimental apparatus with photoelectric cells, but making it more sensitive by developing what he called a 'signal sharpening circuit'.

However, there were still traces of the problems of television in the images that it was able to produce. In the first play to be broadcast in Britain, The Man with a Flower in His Mouth (Figure 3), the time-based problems of delay and synchronisation persisted as actors had to stay close to the cameras so that light was able to be picked up by the photoelectric cells and in both actors had to wear heavy make-up and restrict their movements so that they could be recognised by receivers that were slightly out of synch with the transmitter and split the signal into scan lines that failed ever so slightly to line up. The medium continued to dictate what could and could not be made out on the small receiving screens. The medium necessitated a certain up-closeness, both in terms of the performers' proximity to the cameras and the viewers' proximity to the screen, so that they could make out the image. 
Image 3: Up-closeness.

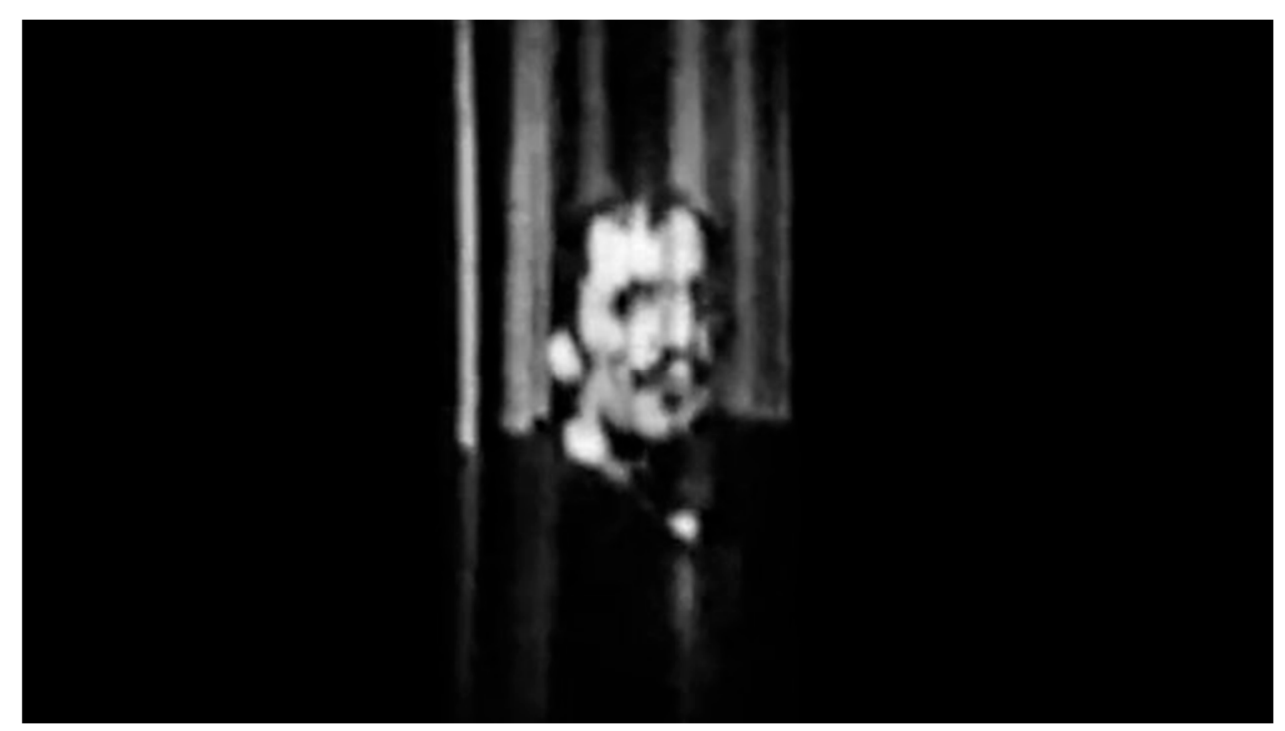

Figure 3. Still from The Man with a Flower in His Mouth (1930) using John Logie Baird's 30 line television system.

The Times featured the following description the day before the broadcast of The Man with a Flower in His Mouth:

The first television play, an adaption of Pirandello's The Man with a Flower in His Mouth, is to be broadcast by the B.B.C. from the Baird studios at 3:30 on Monday afternoon. The production marks an interesting advance in television, for hitherto the broadcasts have consisted of the head and shoulders of just one artist singing or a lecturer talking. In this play that head and shoulders will be seen of each of the three characters-the man, a customer and the woman-as he or she speaks, and not only will the faces of the actors be seen, but there will also be images of their hands, the gestures they make, and other objects illustrating the dialogue [30] (p. 7).

A subsequent article in the The Times, following the broadcast, reported that the play was particularly apt for television as it 'has almost no action, demands no depth of perspective' and 'can be performed without grave loss though but one actor is to be seen at a time' [31] (p. 12). The cultural product fitted into the media temporality of early television and would give this phenomena aesthetic form for the first time.

Actors had to move slowly and deliberately. As the reviewer in The Times stated 'a swift movement would peturb the whole delicate affair and blur the screened image. When this actor's part has finished, the circular screen is past over them and they fade out from view, replaced by another actor, who similarly negotiates between movement and technical constraints' [31] (p. 12). Can we link this to Matt Frei's report, to his efforts to capture the moving, jostling event and turn it into a scene? Are we able to think about the technical image in terms of the way that it can or cannot organise the real? Can we think of the apparatus as struggling to control the contingent, which it itself invited and for which it was waiting? Can we link this to the Bildtelegraph and Ruhmer's discovery? Can we link this history of the television image to the effort to control images through measurement? If, as Kittler has argued, the gramophone radically altered the discourse networks of 1900 due to its ability to preserve the materiality of speech, to record things as they happened, then the television even more profoundly introduced a material apparatus into discussions of epistemology and media history. The television from the start imposed a great deal of constraints on what could be recorded. The gramophone recorded things as they happened, even those things beyond the thresholds of human 
hearing. But the television in some senses made things happen, it conditioned them, providing the context for togetherness in the first place. In this sense the medium was synthetic; it synthesised things and people together and produced new experiences. These new experiences however were restricted by the medium's analytical characteristics, with both performance and viewing routines, as discussed above, conditioned by the way the pick-up apparatus segmented light and the way programmed content fragmented time into episodes.

In The Man with a Flower in His Mouth only the head and shoulders of actors were shown and scenery and object alternately took the place of the actors in front of the camera, always the same size and the same distance from the camera, with transitions provided by a circular screen that was lowered in front of the camera. The proximity of the performers and objects to the camera was to do with the depth of field of the Nipkow disk-based camera and the need for the performer to remain close to the lights was so that the photo-electric cells would register the appropriate amount of reflected light. At this point, based on technical limitations, television found its medium specific qualities and achieved its 'seeing up close', as a particular close inspection of objects and events first afforded by the technical qualities of the media event but soon enhanced by television's serialisation, its place in living rooms, angled towards families intimately sitting in front of its screen.

Television scholars such as Christine Geraghty [32] and Karen Lury [33] have previously pointed to this tendency of television to draw viewers into an 'up-closeness' with its texts. Before Geraghty and Lury, Siegfried Zielinski approaching the medium with a different, more technically oriented, mode of analysis argued that 'the new medium also stood for an important change in the dimensions in which movement appeared visually. The distance between the camera and the objects shifted [as compared to cinema] as did the spatial presence of the visible surfaces on the screen. Televisual seeing became, first and foremost, an act of near-seeing' [emphasis in original] [34] (p. 187).

In full accord with the media archaeological approach, it can be suggested that perhaps this is more than just due to compositional decisions and actually underpinned by the history of the medium as technology, which begins with the recording and transmitting apparatus and is then rehearsed further down the line as the audience, sitting up close to screens, receives the signal on televisors with very small viewing windows. As Swift explained, if you reckon the distance from actor to camera and from screen to viewer, both are only a matter of feet away from one another. Seeing at a distance (the literal meaning of television) was supplanted by a seeing at close proximity. A particular style of viewing was established by this new medium which amounted to an up-closeness, which seemed to give the medium some of its earliest qualities.

Both through its mode of transmission and its artistic content The Man with a Flower in His Mouth deals with what it means to be contemporary, as a particular mediation of being-with-time and the production of different temporal systems. It was an ideal play to be first staged on television not only for its simplicity but because its themes resonated so well with the new medium. At its heart, it is a play about time, given a new temporality via its broadcast and reiterated in its remake in 1967 and now its ability to be accessed on YouTube. The Man with a Flower in His Mouth opens on a scene in a country bar around midnight, established by a painted canvas that can be vaguely seen through the segmentation of the scan lines. In the bar a man, later to be revealed as a dying man, meets a businessman from the city, who has missed his train. The businessman has little regard for time, allowing it to pass by, unable to keep to timetables. The man with the flower in his mouth, on the other hand, carrying with him the aftermath of his diagnosis, lives moment to moment, attempting to fill each one completely. For him, as he explains in the play, time is like a tuft of grass, with his remaining life able to be measured by the discrete blades. For the businessman time is more like the indistinctiveness of a green field, where it is quite usual to miss the right moment to catch a train. In the transmission of the play, time and contemporariness are likewise major themes as the actors' performances are conditioned by the time-based requirements of the medium, including the pace of their gestures and their proximity to the photoelectric cells of the camera, along with the picture becoming vertically cut up, like blades of grass, due to imprecise synchronisation between the transmitter and the receiver. 


\section{Conclusions: What We Learn from the Three Images}

What Claude E. Shannon was so instrumental in showing in his Mathematical Theory of Communication was the way that the major communications inventions of the telephone, television and radio could be reconsidered not as devices that deliver meaning but as devices that transmit information, which could be figured in mathematical language [35]. The voice of the telephone and radio, the audiovision of television, were able to be reduced to information problems and, as Shannon so importantly showed, information could be understood and measured as bits, when samples were taken of a continuous waveform. In terms of the television-it was the time-based problems that had to be solved in order for information to be transmittable and these solutions have come to define the television as a technology of culture. And this is a technology that produces the time of the instant, the fragment, the bit, the pixel.

In this paper I've taken three different images and started to think through the temporality that they produce. The first image was taken from Matt Frei's UK Channel 4 report and demonstrated television's capacity for organizing the event and the temporality of waiting for the contingent that it produces. The second image was Korn's Bildtelegraph, which was used to tease out the idea of the particalisation of time and to historicise the contemporary attempts at the measurement and control of both images and events, which can be seen in the first image. The third image was taken from the first UK television play The Man with a Flower in His Mouth and offered a way to critique the technical qualities of delay and synchronisation that gave TV one of its medium specific characteristics in terms of seeing up-close. In this sense, both image two and image three were investigated in order to historicise the experience of the first image, the nervousness, the tension, the waiting and the idea of a failure to be able to control the events that the television itself both invites and produces. Both image two and image three have shown how the engineering solution to time-based problems not only provided the means for the invention of television but also produced cultural viewing routines. As the reader has now hopefully seen, this argument can then be folded back onto image one, where my initial response to the broadcast was not just a reaction to the events shown on the screen but to the apparatus itself and to an image that has temporarily freed itself from the apparatus. It has been the argument of this essay that images two and three-and the technical discoveries, engineering solutions, and technological operations that they express-set the conditions for the experience of contemporary television. They introduced a type of time that was particalised and only able to be organized by technical means. Of course, contemporary television works hard to erase its technical legacy and to make these qualities of the medium recede into the background. As seen in the Channel 4 report form Paris, the professional norms of television production are aimed at creating a flow, at setting up one thing that dovetails into another, at covering over the medium's fragmentary roots and making it progress according to a line. However, scenes such as the one that started this paper - scenes of crisis-breakthrough this surface and again make visible the temporality of the apparatus. They do this by exceeding the apparatus, by escaping its control, by showing how time might erupt through the organization of scenes.

Funding: This research was funded by a Leverhulme Research Fellowship.

Conflicts of Interest: The author declares no conflict of interest.

\section{References}

1. Smith, T. Art to Come: Histories of Contemporary Art; Duke University Press: Durham, NC, USA, 2019.

2. Flusser, V. Post-History; Rodrigo Maltez Novaes trans.; University of Minnesota Press: Minneapolis, MN, USA, 2013.

3. Agamben, G. What is an Apparatus? And Other Essays; Stanford University Press: Redwood City, CA, USA, 2009.

4. Smith, T. What is Contemporary Art; University of Chicago Press: Chicago, IL, USA, 2009.

5. Osborne, P. Anywhere or Not at All: Philosophy of Contemporary Art; Verso: London, UK, 2013. 
6. Rebentisch, J. The contemporaneity of contemporary art. New German Critique 2015, 42, 223-237. [CrossRef]

7. Williams, R. Television: Technology and Cultural Form; Routledge: Abingdon, UK, 1974.

8. Scannell, P. Radio, Television and Modern Life; Wiley Blackwell: Hoboken, NJ, USA, 1996.

9. Fiske, J. Television Culture; Routledge: Abingdon, UK, 1987.

10. Heath, S. Representing television. In Logics of Television; Mellencamp, P., Ed.; Indiana University Press: Bloomington, IN, USA, 1990; pp. 267-302.

11. White, M. Tele-Advising: Therapeutic Discourse in American Television; The University of North Carolina Press: Chapel Hill, NC, USA, 1992.

12. Stiegler, B. Time and Technics 1: The Fault of Epimetheus; Translated by Richard Beardsworth and George Collins; Stanford University Press: Redwood City, CA, USA, 1998.

13. Virilio, P. The Vision Machine; Translated by Julie Rose; Indianna University Press: Bloomington, IN, USA; Indianapolis, IN, USA, 1994.

14. McQuire, S. Visions of Modernity: Representation, Memory, Time and Space in the Age of the Camera; Sage: London, UK, 1998.

15. Davis, W. Television's Liveness: A Lesson from the 1920s. Westminster Pap. Commun. Cult. 2007, 4, 36-51. [CrossRef]

16. Kittler, F. Optical Media; trans. Anthony Enns; Polity: Cambridge, UK, 2010.

17. Kittler, F. Discourse Networks 1800/1900; trans. Michael Metteer and Chris Cullens; Stanford University Press: Redwood City, CA, USA, 1990.

18. Ernst, W. Chronopoetics: The Temporal Being in Operativity of Technological Media; London and New York; Rowman and Littlefield: Lanham, MD, USA, 2016.

19. Feuer, J. The Concept of live television: Ontology as ideology. In Regarding Television: Critical Approaches; Kaplan, A., Ed.; University Publications of America: Lanham, MD, USA, 1983; pp. 12-22.

20. Deleuze, G. Cinema 2: The Time-Image; Translated by Hugh Tomlinson and Robert Galeta; Conitinuum: New York, NY, USA; London, UK, 2005.

21. Virilio, P. The Aesthetics of Disappeaarnce; Translated by Philip Beitchman; Semiotext(e): Los Angeles, CA, USA, 2009.

22. Hoskins, A.; O'Loughlin, B. War and Media: The Emergence of a Diffused War; Polity: Cambridge, UK, 2010.

23. Patton, P. Events, Becoming and History. In Deleuze and History; Bell, J.A., Colebrook, C., Eds.; Edinburgh University Press: Edinburgh, UK, 2009; pp. 33-53.

24. Peters, J.D. The Marvelous Clouds: Towards a Philosophy of Elemental Media; University of Chicago Press: Chicago, IL, USA; London, UK, 2015.

25. Couldry, N. Liveness, "Reality", and the mediated habitus from television to the mobile phone. Commun. Rev. 2004, 7, 353-361. [CrossRef]

26. Mogensen, K. Television journalism during terror attacks. Media War Confl. 2008, 1, 31-49. [CrossRef]

27. Flusser, V. Into the Universe of Technical Images; trans. Nancy Ann Roth; University of Minnesota Press: Minneapolis, MN, USA, 2011.

28. Burns, R.W. The first demonstration of television. Electron. Power 1975, 21, 953-956. [CrossRef]

29. Doane, M.A. Information, crisis, catastrophe. In New Media/Old Media: A History and Theory Reader; Wendy Hui Kyong Chun, W., Keenan, T., Eds.; Routledge: Abingdon, UK, 2006; pp. 251-264.

30. Upcoming Broadcasts. The Times, 12 July 1930; 7.

31. The First Play by Television. The Times, 15 July 1930; 12.

32. Geraghty, C. Classic television: A matter of time. In The Making and Remaking of Classic Television; University of Warwick: Coventry, UK, 2009; Available online: http://eprints.gla.ac.uk/6562/1/6562.pdf (accessed on 19 May 2016).

33. Lury, K. Interpreting Television; Bloomsbury: London, UK, 2005.

34. Zielinski, S. Audiovisions: Cinema and Television as Entr'actes in History; trans. Gloria Custance; Amsterdam University Press: Amsterdam, The Netherlands, 1999.

35. Shannon, C. A Mathematical theory of information. Bell Syst. Tech. J. 1948, 27, 379-423. [CrossRef] 